DOI: $10.20472 /$ IAC.2018.036.030

\author{
YAHAYA UMAR NAMAHE \\ Umaru Ali Shinkafi Polytechnic, Sokoto, Nigeria
}

\title{
BOKO HARAM UPRISING AND FORCED MIGRATION IN NIGERIA
}

\begin{abstract}
:
Forced migration in and into Nigeria was caused by several reasons such as environmental degradation and natural disasters, inter and intra communal/ inter-ethnic clatters, boundary clashes between native people and settlers, disagreements over land, electoral violence, as well as violent conflicts. However, the most devastating armed conflict that has led to force migration of people in recent times particularly in the northeastern part of the Nigeria is the Boko Haram uprising. Reports have showed that, over two million people were forced to move out from their original homes as a result of the crisis. This paper therefore, seeks to examine the nature, growth and consequences of the crisis. The paper also tries to highlights the effects of the crisis on the plight of the displaced people in terms of their living conditions, food and nutrition, health, security and education. The paper finally offers some recommendations with a view of improving the situation.
\end{abstract}

\section{Keywords:}

Boko Haram, Migration, uprising 